\title{
Boom and Gloom in Housing Markets: The Sequel
}

\author{
Carlos Garriga
}

$\mathrm{T}$ he effect that housing has on the economy has received increased attention in recent years-first for the recordhigh boom in house prices and homeownership and then for the decline in house prices and the subprime market meltdown. Part of the boom was fostered by important developments in housing finance such as the introduction of new mortgage products, a reduction in the cost of providing mortgage services, and the expansion of subprime lending and private securitization of mortgages. For example, instruments such as "piggyback" loans and option adjustable-rate mortgages accounted for 12.5 percent of the originations in 2004 and 32.1 percent in 2006.

Mortgage market innovations and their importance in increasing house prices and homeownership have a historical precedent: After the collapse of mortgage markets during the Great Depression, policymakers' goal was to increase owner-occupied housing. In the late 1930s, the creation of the Federal Housing Administration (FHA) led to changes in the terms of existing mortgage contracts. Prior to the Great Depression, the typical mortgage contract had a maturity of less than ten years, a 50 percent downpayment, no amortization, and a balloon payment at expiration. The FHA sponsored the use of a new mortgage with a longer duration, lower downpayment requirement, and self-amortizing structure. Government intervention provided uniform lending throughout the country that resulted in low and stable mortgage rates. Between 1942 and 1947, house prices and homeownership attained historical heights with an annual inflation-adjusted appreciation of 6.5 percent and a total increase in owner-occupied housing of 20 percent. Shortages of building materials and delays in construction of housing for low-income families fueled the house price boom, followed by a bust once the supply of new construction caught up.

The similarities between these time periods become clear by plotting inflation-adjusted U.S. house prices (see the chart), which suggests that periods following innovations in housing finance also include high appreciation. The magnitudes of the house price increases from both periods are qualitatively the same when the OFHEO index is used, and the most recent period is slightly higher (10 percent) according to the Case-Shiller index.
However, the homeownership rate differs substantially across periods. Innovations in housing finance after the Great Depression reduced the barriers to homeownership for many middle-income households. These individuals had at least 20 percent of equity in the house to buffer a large decline in the price. That, combined with some legal restrictions to "walk away" from the house, kept the foreclosure rates at historically low levels.

By contrast, the innovations in the past decade allowed firsttime (young and low-income households) and repeat buyers to purchase or refinance a house with a very low or even no downpayment. These low levels of equity have increased homeowners' exposure to the widespread decline in house prices and have triggered the current higher level of foreclosures. The Housing and Vacancies Survey (HVS/CPS) reports that the largest drop in homeownership in the period 2004-07 involves individuals between age 45 and 54; in fact, most of this group's increase in participation since the early 1990s has been completely wiped out. Moreover, the decline for individuals age 44 and younger has been around 50 percent.

Thus, this experience shows that homeownership is not necessarily the best housing option for highly leveraged households more prone to foreclosure. 